\title{
Belajar Kemahiran Berbahasa Asing Mahasiswa Fakultas Sastra Melalui Aktifitas dan Program Kerja Organisasi Kemahasiswaan (Studi Analisis Program Kerja Organisasi Mahasiswa)
}

\author{
Faisal Hendra ${ }^{1}$, Zulkarnen ${ }^{2}$ \\ ${ }^{1,2}$ Program Studi Sastra Arab, Fakultas Sastra, Universitas Al Azhar Indonesia \\ Kompleks Masjid Agung Al Azhar, Jalan Sisingamangaraja, Kebayoran Baru, Jakarta Selatan 12110
}

Penulis untuk Korespondensi/E-mail: faisal_2014@uai.ac.id

\begin{abstract}
Abstrak - Penelitian ini berjudul, Belajar Kemahiran Berbahasa Asing Mahasiswa Fakultas Sastra Melalui Aktifitas dan Program Kerja Organisasi Kemahasiswaan (Studi Analisis Program Kerja Organisasi Mahasiswa). Penelitian ini dilakukan untuk melihat sejauhmana tingkat partisipasi dan keikutsertaan mahasiswa Fakultas Sastra yang tergabung dalam organisasi mahasiswa dalam menjalankan program kerja organisasi mereka berbasis kemahiran berbahasa yang diopelajari di Fakultas Sastra. Penelitian ini bersifat kualitatif, dari hasil yang diperoleh, peneliti menganalisa dan menarasikan data-data yang didapatkan. Dari hasil penelitian diketahui bahwa, Fakultas Sastra UAI dalam membina organisasi kemahasiswaan mahasiswa sudah melakukan pembinaan dengan baik, walaupun masih perlu ditingkatkan kualitas dan kuantitasnya. Konsep kekeluargaan menjadi dasar pengelolaan organisasi di FS. Program kerja yang dibuat dan dilaksakan oleh organisasi kemahasiswaan ada yang sudah menunjang proses pembelajaran kemahiran berbahasa, ada juga yang tidak. Masih perlu ditingkatkan lagi bentuk dan pengelolaan program kerjanya. Untuk partisipasi, keaktifan dan keikutsertaan mahasiswa Fakultas Sastra yang tergabung dalam organisasi dalam mengelola organisasi mereka masih beragam. Tingkat partisipasi mereka dimasingmasing organisasi berbeda, ada yang kecil ada juga yang sudah masuk kategori baik.
\end{abstract}

\section{Kata kunci - Kemahiran Berbahasa, Aktifitas, Program Kerja, Organisasi Kemahasiswaan}

Abstract - This study entitled, Learning Proficiency in Foreign Language for Students Faculty of Letters through Activities and Student organization's Work Program (the Analyzation within the Student Organization's work program). This research was conducted to see how far the participation and involvement of students in Faculty of Letters, those who joined in the student's organization, in running their organization work program based on the language proficiency studied in the Faculty of Letters. This research is qualitative. It has conducted by the researcher's analyzation and narration from the data obtained. The results of the research shows that, UAI Faculty of Letters have done good coaching in fostering it student organizations, although it still needs improvement in its quality and quantity. The concept of kinship becomes the basis of organizational management in FS. The student organization has created work programs. Some of the work program that has been implemented by the student organizations supported the learning process language skills, yet some others are not. The student organization still needs to improve the form and management of the work program. The students in Faculty of Letters conduct their participation (in term of being active and cooperative within working on the work program) diversely. Some shows very little effort of participation in the work program, and others shows very good effort of participation. 


\section{PENDAHULUAN}

$\mathrm{K}$ emahiran berbahasa asing yang empat (mendengar, berbicara, menulis dan membaca) merupakan kemahiran penting yang ingin dicapai dalam proses pembelajaran bahasa asing, khususnya di Fakultas Sastra, Universitas Al Azhar Indonesia (UAI).

Zaid Barakah (2000), menyatakan bahwa dalam pembelajaran bahasa, setidaknya ada lima unsur yang sangat mempengaruhi keberhasilan pembelajaran bahasa asing, kelima unsur ini adalah: Tujuan Pengajaran, Bahan Ajar, Metode Pengajaran, Media Pengajaran/Alat Peraga, dan Evaluasi Akhir.

Dalam pengelolaan dan menjalankan kurikulum di Universitas Al Azhar Indonesia, pelaksanaannya diemban oleh pihak yang terkait dengan struktur birokrasi Universitas, mulai dari tingkat rektorat sampai tingkat pelaksana di program studi. Tim pengajar/dosen adalah ujung tombak pelaksanaan kurikulum di tingkat pelaksanaan. Pihak yang terlibat langsung sebagai pelaksana kurikulum tentunya adalah koordinator bidang studi dan dosen pengajar bahasa asing. Di tingkat Universitas, ketua program studi bertanggung jawab mengambil kebijakan dan melakukan langkah-langkah yang diharapkan dapat menunjang keberhasilan proses belajar mengajar bahasa asing yang dipelajari. Adapun dosen bertanggung jawab atas terlaksananya proses belajar-mengajar, membuat perencanaan, mengembangkan metodologi pembelajaran, dan meningkatkan kompetensi keilmuannya dalam bidang bahasa. Pada saat yang sama mahasiswa sebagai objek dalam penerapan kurikulum dengan organisasi kemahasiswaan yang dimiliki dan dengan program kerja yang terstruktur juga sangat diharapkan mampu menterjemahkan penerapan kurikulum ini dengan berbagai aktifitas yang mendukung tercapainya proses pembelajaran yang dilaksanakan. Ketiga pihak inilah yang pada teorinya sangat menentukan tujuan yang ingin dicapai dalam penerapan kurikulum, di Fakultas Sastra UAI.

Mahasiswa sebagai sasaran akhir dalam penerapan kurikulum yang didesain oleh pengelola pendidikan dituntut harus aktif dalam menterjemahkan setiap target yang ingin dicapai dalam proses pembelajaran yang dilaksanakan. Untuk melihat sejauh mana organisasi kemahasiswaan ditingkat fakultas dan program studi yang ada di Fakultas Sastra menjadikan program kerja organisasi mereka sebagai bagian dari peningkatan kemampuan mereka berbahasa asing maka dilakukanlah penelitian ini. Hasil penelitian ini diharapkan dapat menjadi bahan dalam pembinaan mahasiswa Fakultas Sastra kedepannya untuk para dosen, prodi dan fakultas.

\section{Tujuan dan Manfaat Penelitian}

Penelitian ini bertujuan untuk mengevaluasi pola pembinaan organisasi kemahasiswaan yang ada di Fakultas Sastra, serta mendorong mahasiswa untuk menselaraskan antara program kerja yang dibuat oleh organisasi kemahasiswaan dengan tujuan pembelajaran kemahiran berbahasa yang dicanangkan oleh Program Studi di Fakultas Sastra, Universitas Al Azhar Indonesia.

Batasan Masalah dan Pertanyaan Penelitian Penelitian ini fokus kepada pola pembinaan mahasiswa lewat organisasi kemahasiswaan dengan program kerjanya mencapai tujuan pembelajaran pengajaran bahasa asing di Fakultas Sastra. Sementara untuk batasan penelitian, diturunkan dalam bentuk pertanyaan sebagai berikut:

1. Bagaimanakah pola pembinaan Fakultas Sastra dan Program Studi (Arab, China, Inggris, Jepang) dalam membina organisasi kemahasiswaan?

2. Program apa sajakah yang dicanangkan oleh organisasi mahasiswa dalam mendukung proses pembelajaran kemahiran berbahasa?

3. Melihat sejauhmana tingkat partisipasi mahasiswa dalam menjalankan program kerja organisasi kemahasiswaan di Fakultas Sastra, yang dijadikan sebagai bagian dari upaya mereka dalam meningkatkan kemampuan berbahasa asing di prodi masing-masing?

\section{KERANGKA TEORI}

\section{Kemampuan}

Mampu berarti kuasa (bisa, sanggup) melakukan sesuatu; dapat; berada; kaya; mempunyai harta berlebih. Kemampuan adalah kesanggupan; kecakapan; kekuatan. Seseorang dikatakan mampu apabila ia bisa atau sanggup 
melakukan sesuatu yang harus ia lakukan. Kemampuan adalah kapasitas seorang individu untuk melakukan beragam tugas dalam suatu pekerjaan. Kemampuan adalah sebuah penilaian terkini atas apa yang dapat dilakukan seseorang.

Mohammda Zain dalam Milman Yusdi, mengartikan bahwa kemampuan adalah kesanggupan, kecakapan, kakuatan kita berusaha dengan diri sendiri. Sedangkan Anggiat M.Sinaga dan Sri Hadiati mendefenisikan kemampuan sebagai suatu dasar seseorang yang dengan sendirinya berkaitan dengan pelaksanaan pekerjaan secara efektif atau sangat berhasil.

Sementara itu, menurut Robbin kemampuan berarti kapasitas seseorang individu untuk melakukan beragam tugas dalam suatu pekerjaan. lebih lanjut Robbin menyatakan bahwa kemampuan (ability) adalah sebuah penilaian terkini atas apa yang dapat dilakukan seseorang.

Berdasarkan pengertian diatas dapat disimpulkan bahwa kemampuan adalah kecakapan atau potensi seseorang individu untuk menguasai keahlian dalam melakukan atau mengerjakan beragam tugas dalam suatu pekerjaan atau suatu penilaian atas tindakan seseorang.

Pada dasarnya kemampuan terdiri atas dua kelompok faktor, yaitu:

1. kemampuan intelektual (intelectual ability) yaitu kemampuan yang dibutuhkan untuk melakukan berbagai aktifitas mentalberfikir, menalar dan memecahkan masalah.

2. kemampuan fisik (physical ability) yaitu kemampuan melakukan tugas-tugas yang menuntut stamina, keterampilan, kekuatan, dan karakteristik serupa.

\section{Faktor Pendukung Kemampuan}

Robbin menyatakan bahwa faktor pendukung kemampuan seseorang adalah sebagai berikut :

1. Faktor internal, yaitu faktor yang berasal dari dalam diri seseorang baik jasmani (fisiologis) maupun rohani (psikologis). Faktor fisiologis yaitu kondisi umum jasmani dan tonus (tegangan otot)yang menandai tingkat kebugaran organ-organ tubuh dan sendi-sendinya dapat mempengaruhi semangat dan intensitas seseorang dalam mengikuti pelajaran.

2. Faktor eksternal, selain dari faktor internal, pembelajaran juga dipengaruhi oleh faktor eksternal, yaitu faktor yang berasal dari luar diri seorang. Faktor eksternal ini dibagi menjadi dua, yaitu lingkugan (baik yang berasal dari alam maupun sosial budaya) dan instrumental (fasislitas serta media yang disediakan di lembaga pendidikan).

\section{Belajar Bahasa}

Banyak kajian dilakukan untuk mengamati bagaimana anak memperoleh bahasa dalam lima tahun pertama dalam hidupnya. Di Indonesia, kajian semacam itu dilakukan oleh para pakar linguistik, diantaranya Sunjono Dardjowidjojo (2000). Ia mengamati perkembangan bahasa cucunya yang bernama Echa selama lima tahun. Dalam lima tahun Echa, sang cucu ternyata telah dapat menguasai bahasa Indonesia yang dapat digunakan untuk berkomuniaksi. Studi semacam itu juga sudah banyak dilakukan oleh pakar-pakar dari negaranegara Barat untuk menyingkap tabir rahasia anak belajar bahasa.

Dalam pembelajaran bahasa terdapat beberapa teori yang sangat berbeda pendapatnya. Kelompok pertama, yakni yang berorientasi pada psikologi behaviorisme, yang kedua adalah pendekatan generatif yang berakar pada teori psikologi nativisme dan teori psikologi kognitivisme, sedangkan yang ketiga ialah pendekatan fungsional yang berakar pada psikologi konstruktivisme. Ketiga teori itu ternyata mempunyai pengaruh yang sangat kuat dalam dunia ilmu bahasa. Oleh sebab itu, ketiga teori itu akan kita bicarakan satu per satu dalam ulasan berikut ini.

\section{Teori Behavioris}

Bahasa merupakan bagian fundamental dari keseluruhan perilaku manusia. Demikianlah kaum behavioris melihat bahasa dan kaum behavioris mencoba untuk memformulasikan teori yang taat asas tentang pemerolehan bahasa pertama. Pendekatan behaviorisme memumpunkan perhatiannya pada aspek yang dapat dirasakan secara langsung pada perilaku berbahasa dan hubungan antara respons dan peristiwa di dunia yang mengelilinginya. Seorang behavioris menganggap bahwa perilaku berbahasa yang efektif merupakan hasil respons tertentu yang dikuatkan, respons 
itu akan menjadi kebiasaan atau terkondisikan. Jadi, anak dapat menghasilkan respons kebahasaan yang dikuatkan, baik respons yang berupa pemahaman atau respons yang berwujud ujaran. Seseorang belajar memahami ujaran dengan mereaksi stimulus secara memadai dan ia memperoleh penguatan untuk reaksi itu.

\section{Teori Generatif}

Pembicaraan tentang berbagai teori belajar bahasa itu dapat diibaratkan sebagai sebuah kontinuum. Di ujung yang satu berdiri tegak teori behaviorisme dan di ujung lain berdiri kukuh teori yang akan kita bahas sekarang ini, yakni teori generatif. Teori generatif mengguakan pendekatan rasionalistik. Teori itu melemparkan pertanyaan yang lebih dalam untuk mencari penjelasan yang gamblang dan jelas tentang rahasia pemerolehan dan belajar bahasa. Kegagalan atau setidak-tidaknya penjelasan yang masih bersifat parsial dari pandangan behaviorisme tentang bahasa anakanak menyebabkan kita bertanya lebih banyak lagi. Tidak ada penelitian ilmiah yang menunjukkan kedalamannya dan ketuntasannya.

Ada dua tipe teori generatif yang telah membuat markanya masing-masing dalam penelitian bahasa. Keduanya beragih ujung yang sama pada kontinuum. Tipe pertama ialah golongan nativis dan kedua ialah golongan kognitivis.

\section{a. Nativisme}

Istilah nativisme dihasilkan dari pernyataan mendasar bahwa pembelajaran bahasa ditentukan oleh bakat. Bahwa kita dilahirkan itu sudah memiliki bakat untuk memperoleh dan belajar bahasa. Teori tentang bakat bahasa itu memperoleh dukungan dari berbagai sisi. Eric Lenneberg (1967) membuat proposisi bahwa bahasa itu merupakan perilaku khusus manusia dan bahwa cara pemahaman tertentu, pengkategorian kemampuan, dan mekanisme bahasa yang lain yang berhubungan ditentukan secara biologis.

\section{b. Kognitivisme}

Kerangka nativis pun masih mempunyai kelemahan-kelemahan. Akhir tahun 60-an merupakan saksi pergeseran kontinuum, tetapi bergerak lebih pada hakikat bahasa. Kaidah generatif yang diproposisikan oleh kelompok nativis itu merupakan sesuatu yang abstrak, formal, eksplisit, dan logis, meskipun mereka berkaitan khususnya dengan bahasa dan buka tataran bahasa yang sangat dalam, pada tataran di mana ingatan, persepsi, pikiran, makna, dan emosi diorganisasikan secara berhubungan struktur super pikiran manusia.

\section{Organisasi Mahasiswa}

Secara teori, organisasi mahasiswa dapat diartikan adalah sebuah wadah berkumpulnya sekumpulan mahasiswa demi mencapai tujuan bersama, dan mempunyai visi dan misi yang jelas serta disetujui oleh semua pengurus organisasi tersebut. Organisasi mahasiswa intrakampus adalah organisasi mahasiswa yang memiliki kedudukan resmi di lingkungan perguruan tinggi dan mendapat pendanaan kegiatan kemahasiswaan dari pengelola perguruan tinggi dan atau dari kementerian atau lembaga terkait. Bentuknya dapat berupa organisasi mahasiswa ditingkat Universitas, organisasi kemahasiswaan tingkat Fakultas, organisasi kemahasiswaan tingkat Program Studi. Ada juga organisasi kemahaiswaan berdasarkan minat dan bakat mahasiswa, yang dinamakan dengan Unit Kegiatan Mahasiswa yang disingkat UKM.

Organisasi secara umum dipandang sebagai sebuah budaya, memberi peluang untuk penafsiran budaya. Sebuah organisasi bisa jadi merupakan cara pandang anggotanya, menciptakan realitas bersama yang berbeda dari budaya lainnya. Morgan (1986: 128) menjelaskan: Pemaknaan bersama, pemahaman bersama dan menciptakan perasaan bersama adalah cara yang berbeda untuk menggambarkan budaya. berbicara tentang budaya berarti berbicara tentang sebuah proses penmbentukan realitas yang memungkinkan orang untuk melihat dan memahami kejadian khusus, tindakan, objek, ucapan dan situasi dalam cara yang unik. Budaya organisasi terbentuk melalui interaksi antaranggota.

Secara peraturan Perundang-undangan yang ada di Indonesia, organisasi mahasiswa telah memiliki payung hukum yang menjamin keberadannya yaitu sesuai dengan PP. No. 60 tahun 1999 tentang Perguruan Tinggi yang kemudian secara teknis dilindungi Keputusan Menteri Pendidikan dan Kebudayaan Republik Indonesia No. 155/U/1998. Banyak hal yang dijelaskan dalam peraturan tersebut baik 
kedudukun, fungsi, tanggung jawab, hingga mengenai persoalaan pendanaan organisasi mahasiswa berasal dan dialokasikan dari kampus atau sumber lain yang tidak bertentangan dengan peraturan Perundangundangan yang berlaku.

Secara umum ada beberapa manfaat organisasi kemahasiswaan bagi mahasiswa, dianataranya adalah:

a. Menjadi wadah untuk mengembangkan ilmu pengetahuan

b. Menjadi alat atau media dalam melatih diri mempraktekan keilmuan formil yang dipelajari di kampus

c. Mengasah kemampuan sosial secara indifidu mahasiswa dalam kehidupan bermasyarakat

d. Memperluas jejaring pergaulan mahasiswa berbasis Prodi dan lain-lain

e. Belajar mengatur waktu yang ada, pendidikan dan non pendidikan

f. Meningkatkan wawasan dan pengetahuan, baik ilmu pendidikan maupun ilmu penunjang

g. Membentuk pola pikir mahasiswa yang lebih baik di kampus dan luar kampus

h. Menjadi pribadi yang kuat dalam menghadapi tekanan, baik pendidikan maupun luar pendidikan

i. Meningkatkan kemampuan berkomunikasi dan adaptasi sehari-hari

j. Melatih dan menumbuhkan peran leadership seseorang atau kepemimpinan

k. Memperluas dan membangun jaringan dan kerjasama (networking)

1. Menjadi tempat latihan sebelum masuk kedalam dunia kerja yang sesungguhnya

\section{METODE PENELITIAN}

Penelitian ini bersifat kualitatif, dari data yang diperoleh, peneliti melakukan analisa secara detil dan menarasikan data-data yang didapat dilapangan terkait judul yang dipilih dalam penelitian ini.

Populasi target penelitian ini adalah seluruh pihak yang terlibat dalam pembinaan mahasiswa baik mahasiswa sebagai personal, maupun mahasiswa sebagai bagian dari anggota organisasi kemahasiswaan, diantara populasi target adalah: dekan fakultas, ketua dan sekretaris program studi, dosen pembina mahasiswa, serta pengurus organisasi kemahasiswaan dilingkungan Fakultas Sastra, UAI.

\section{Subjek Penelitian}

Dalam penelitian ini, karakteristik subjek adalah Sebagai berikut :

Subjek penelitian ini adalah dekan fakultas, ketua dan sekretrais Program Studi, dosen pembinan mahasiswa tingkat fakultas serta pengurus organisasi mahasiswa yang ada baik ditingkat fakultas maupun dari organisasi mahasiswa dari empat program studi yang ada di Fakultas Sastra (sastra Arab, China, Inggris dan Jepang), Universitas Al Azhar Indonesia. Analisa penelitian mengacu kepada pembuatan program kerja tahunan oleh masing-masing organisasi kemahasiswaan yang ada dan korelasinya dengan kurikulum pembelajaran bahasa yang digunakan dimasing-masing program studi yang ada di Fakultas Sastra.

\section{Tahapan Penelitian}

\section{Tahap Persiapan Penelitian}

Pertama peneliti membuat pedoman pengumpulan data dan wawancara yang disusun berdasarkan demensi kebermaknaan sesuai dengan permasalahan dan pekerjaan yang ditekuni subjek. Selanjutnya mencari subjek yang sesuai dengan karakteristik subjek penelitian. Sebelum pengumpulan data dilaksanakan peneliti bertanya kepada subjek tentang kesiapanya untuk mengisi data dan diwawancarai. Setelah subjek menyatakan kesediaannya untuk didata dan bersedia untuk diwawancarai, peneliti membuat kesepakatan dengan subjek tersebut mengenai waktu dan tempat untuk melakukan wawancara.

\section{Tahap pelaksanaan penelitiaan}

Peneliti membuat kesepakatan dengan subjek mengenai waktu dan tempat untuk melakukan pengisian data dan proses wawancara berdasarkan pedoman yang telah dibuat. Setelah pengisian data dan wawancara dilakukan, peneliti memindahkan hasil rekapan data dan wawancara yang dilakukan berdasarkan dalam bentuk tertulis. Selanjutnya peneliti melakukan analisis data dan interprestasi data sesuai dengan langkah-langkah yang dijabarkan pada bagian metode analisis data di akhir bab ini. setelah itu, peneliti 
membuat analisa. Setelah mendapatkan hasil dari penelitian yang dilakukan, peneliti merangkum hasilnya dalam bentuk kesimpulan, dibagian akhir peneliti memberikan saran-saran untuk pengambangan penelitian ini selanjutnya.

\section{Teknik Pengumpulan Data}

Dalam penelitiaan ini, peneliti menggunakan dua teknik pengumpulan data, wawancara dan observasi yang yang dikuatkan dengan angket yang harus diisi oleh objek yang berasal dari pengurus organisasi kemahasiswaan di Fakultas Sastra UAI.

\section{Alat Bantu pengumpulan Data \\ Dalam mengumpulkan data-data penulis membutuhkan alat bantu (instrumen penelitian). Dalam penelitian ini peneliti menggunakan 2 alat bantu, yaitu: Pedoman wawancara dan Angket.}

\section{ANALISIS PENELITIAN}

\section{Mengenal Organisasi Mahasiswa Fakultas Sastra UAI}

Universitas Al Azhar Indonesia (UAI), sebagai universitas yang masih tergolong universitas baru, yang didirikan pada tahun 2000, berusaha untuk memberikan kesempatan kepada mahasiswanya untuk memperkaya kemampuan soft skill mereka dalam wadah organisasi kemahasiswaan intra kampus yang ada. Diantara bentuk terobosan yang dilakukan adalah, pada tahun 2005, UAI membuat ciri khusus pada organisasi kemahasiswaan yang ada di Universitas Al Azhar Indonesia (UAI). Kalau organisasi intra kampus di universitas lain menggunakan kata dan sistem PRESMA (Presiden Mahasiswa). Di UAI yang digunakan adalah konsep kekeluargaan dengan memilih nama KMU (Keluarga Mahasiswa Universitas), begitu juga ditingkat fakultas, program studi dan organisasi berdasarkan minat dan bakat. Pemberian nama selalu mencantumkan kata keluarga, dengan asumsi bahwa mahasiswa dalam organisasi mereka, pengelolaannya harus dibangun dengan dua semangat, semangat profesionlisme pengelolaan organisasi atas dasar semangat kekeluargaan.

\section{Keluarga Mahasiswa Fakultas Sastra (KMFS)}

Organisasi kemahasiswan di Fakultas Sastra, dibagi kedalam dua jenis. Organisasi mahasiswa ditingkat Fakultas diberinama Keluarga Mahasiswa Fakultas Sastra yang disingkat dengan KMFS dengan Dekan Fakultas Sastra sebagai pembinanya, dan organisasi mahasiswa ditingkat program studi yang diberinama dengan Keluarga Mahasiswa Program Studi yang disingkat dengan (KMPS) dengan Ketua Program Studi sebagai pembinanya. KMFS hanya ada satu sementara KMPS ada empat sesuai dengan jumlah program studi yang ada di FS UAI, yaitu: KMPS Arab, KMPS China, KMPS Inggris dan KMPS Jepang.

Diantara tugas dan peran KMFS dalam pembinaan organisasi mahasiswa dan anggota di FS adalah sebagai berikut:

- Merencanakan dan melaksanakan kegiatan organisasi kemahasiswaan tingkat Fakultas Sastra berdasarkan semangat pengelolaan Tridharma Perguruan Tinggi dan Visi Misi Universitas Al Azhar Indonesia di tingkat Fakultas Sastra.

- Ikut terlibat dalam kegiatan lomba-lomba, penelitian, seminar, workshop dan sebagainya, ditingkat Fakultas Sastra, universitas, nasional, maupun internasional.

- Melakukan koordinasi kegiatan kemahasiswaan dengan Fakultas Sastra sebagai penanggung jawab pembinaan mahasiswa tingkat Fakultas.

- Melakukan koordinasi kegiatan kemahasiswaan dengan Koordinator Kemahasiswaan yang ada ditingkat Fakultas Sastra.

- Melakukan kaderisasi tingkat Fakultas dan lintas Prodi untuk menjaga kesinambungan kepemimpinan organisasi mahasiswa di Fakultas Sastra.

Sementara peran organisasi mahasiswa ditingkat Program Studi dibawah Fakultas Sastra, yang dinamakan dengan Keluarga Mahasiswa Program Studi (KMPS), adalah sebagai berikut:

- Merencanakan dan melaksanakan kegiatan kemahasiswaan yang yang tergabung dibawah organisasi mahasiswa tingkat program studi yang ada di Fakultas Sastra, yang berkaitan dengan pengembangan 
penalaran dan keilmuan serta sikap, profesi sesuai bidang ilmu dan program studi, yang sesuai visi misi Universitas Al Azhar Indonesia dan Tridharma perguruan tinggi.

- Ikut aktif mengikuti kegiatan lomba-lomba, penelitian dan dan tri dharma perguruan tinggi ditingkat program studi, fakultas, universitas, nasional, maupun internasional.

- Menyelenggarakan proses kaderisasi untuk organisasi tingkat Program Studi dilingkungan Fakultas Sastra UAI.

- Membuat dan melaporkan laporan pertanggung jawaban seluruh kegiatan kemahasiswaan dibawah organisasi mahasiswa kepada Ketua Program Studi, dan selanjutnya diserahkan ke Universitas melalui Biro Kemahasiswaan.

- Melakukan koordinasi kegiatan kemahasiswaan dengan Koordinator Kemahasiswaan yang ada di Fakultas Sastra.

\section{Anilisis Penelitian}

Sesuai dengan tema penelitian ini, peneliti membagi angket kepada responden dilihat empat komponen, yang terdiri dari: bagian pertama dilihat pandangan mahasiswa sebagai pengurus organisasi tentang keberadaan organisasi mahasiswa dan cara mereka membuat program kerja organisasi. Dibagian kedua dilihat pandangan mahasiswa sebagai pengurus organisasi, dalam membuat program kerja organisasi sebagai alat peningkatan kemahiran berbahasa di fakultas sastra. Bagian ketiga dilihat program kerja organisasi mahasiswa ditingkat KMFS dan KMPS dari masing-masing devisi yang ada, yang mendukung pengajaran kemahiran berbahasa di Fakultas Sastra UAI (kemahiran mendengar, berbicara, membaca, menulis). Dibagian akhir, bagian empat penulis ingin melihat pendapat mahasiswa sebagai pengurus secara umum tentang peran organisasi kemahasiswaan yang ideal yang perlu dikembangkan di FS UAI kedepan, dalam meningkatkan kemampuan kemahiran berbahasa asing mahasiswa.

\section{Pandangan Mahasiswa Sebagai Pengurus Organisasi tentang Keberadaan Organisasi dan Cara Membuat Program Kerja Organisasi}

Keberadaan organisasi mahasiswa di tingkat Fakultas dan Program Studi di Fakultas Sastra, Universitas Al Azhar Indonesia dengan KMF dan KMPS nya merupakan sebuah keharusan. Organisasi adalah wadah bagi para mahasiswa untuk bisa mengekspresikan diri dan menyampaikan aspirasi yang mereka miliki. Setelah dilakukan penelitian kepada mahasiswa penggurus organisasi mahasiswa ditingkat Fakultas dan Program Studi di FS UAI didapatkan data bahwa, mayoritas pengurus organisasi mengatakan bahwa keberadaan organisasi sangat penting ada di dalam setiap perguruan tinggi, ditingkat fakultas dan ditingkat program studi, karena dengan adanya organisasi akan bisa menampung banyak ide dan pengembangan kreatifitas seluruh mahasiswa. Mahasiswa FS sangat menyadari bahwa organisasi bisa digunakan sebagai tempat atau wadah dimana dijadikan sebagai tempat mahasiswa berkumpul, bekerjasama secara rasional dan sistematis, terencana, terorganisasi, terpimpin dan terkendali, dalam memanfaatkan sumber daya, sarana-parasarana, data dan lain sebagainya yang digunakan secara efisien dan efektif untuk mencapai tujuan organisasi yang mereka kelola. Apalagi keberadaan organisasi berbasis keilmuan yang dipelajari. KMPS Sastra Arab, China, Inggris dan Jepang misalnya, dengan tergabungnya mahasiswa dibawah satu wadah, mereka akan merasa lebih terpanggil untuk berkontribusi dalam bidang kebahasaaan yang mereka pelajari, sulit untuk memisahkan antara berorganisasi hanya untuk melatih soft skill sementara pada saat yang bersamaan mereka juga dituntut untuk berprestasi dibidang akademik, khusus nya di kemahiran berbahasa. Maka akhirnya menjadi keharusan untuk menselaraskan keberadaan mereka di organisasi dengan peran mereka sebagai mahasiswa program studi.

Muncul pertanyaan, bagaimana menjadikan organisasi mahasiswa sebagai bagian dari alat dalam membantu proses pembelajaran, khususunya kemahiran berbahasa yang empat? Pertanyaan ini diterjemahkan oleh peneliti dalam bentuk pernyataan yang ditujukan kepada mahasiswa pengurus organisasi mahasiswa ditingkat KMF dan KMPS. Pernyataan yang diberikan adalah: Program kerja organisasi mahasiswa di FS UAI dibuat oleh pengurus organisasi yang menjalankan organisasi dengan melibatkan pengurus organisasi dan anggota masing-masing organisasi. Dari hasil analisis dan diperkuat dengan observasi dilapangan yang dilakukan, 
didapatkan data bahwa tingkat kesadaran mahasiswa FS berorganisasi secara umum sudah baik, mereka menyadari bahwa tidak mungkin organisasi mereka bisa berjalan kalau bukan mereka yang menjalankannya. Juga tidak akan mungkin program kerja yang telah dibuat bisa berjalan, kalau bukan dijalankan oleh mereka sendiri sebagai pengurus organisasi. Secara umum kesadaran penting bergabung dalam satu wadah organisasi, dan seorang pengurus harus membuat program kerja organisasi sebagai konsekwen keberadaan mereka sebagi pengurus, sudah tertanam dalam diri mahasiswa FS dengan baik, bahkan ketika membuat program kerja tahunan mahasisw Fakultas Sastra sudah berusaha untuk membuat program kerja tidak bekerja secara indifidu, akan tetapi mereka membuatnya dengan beberapa tahapan, yang diantaranya melibatkan banyak stake holder, khususnya anggota mahasiswa dari organisasi yang mereka pimpin dan minta saran dan pendapat dari kakak tingkat, serta mau membangun komunikasi dengan organisasi kemahasiswa di Fakultas dan Program Studi yang lain yang ada di UAI.

Dalam pengelolaan organisasi kemahasiswan yang benar, anggota sebagai objek yang akan dikelola harus dilibatkan dalam perencanaan program sebagai bagian dalam melakukan aktivitas analisis kebutuhan organisasi. Anggota harus mengetahui sumber daya dan kebutuhan organisasi sehingga dapat digunakan dalam perumusan rencana program. Setelah melakukan analisis kebutuhan, maka perumusan rencana program yang tepat diputuskan pada tingkatan pimpinan organisasi. Pimpinan yang menggunakan seluruh hasil analisa sebagai dasar pengambilan keputusan rencana program yang tepat dalam menjawab kebutuhan organisasi. Dengan begitu perencanaan program kerja organisasi akan lebih efektif, dan tetap melibatkan seluruh anggota organisasi.

Disisi lain, dari data yang ditemukan dilapangan dalam pengelolaan organisasi mahasiswa, masih terlihat cara pandang yang berbeda pengurus organisasi mahasiswa dalam melihat sejauhmana perlunya satu organisasi kemahasiswaan ditingkat Fakulktas dan Program Studi di Fakultas Sastra UAI melibatkan program studi dalam membuat dan mendesain program kerja tahunan organisasi. Perbedaan cara pandang ini peneliti dapatkan, ketika mahasiswa diminta untuk menyikapi peryataan yang menyakatan: Program studi tidak perlu dilibatkan dalam membuat program kerja organisasi mahasiswa atas dasar prinsip organisasi mahasiswa dari mahasiswa dan untuk mahasiswa. Ketika disampaikan peryataan ini, jawaban pengurus organisasi yang ada di FS UAI cukup beragam, ada yang mengatakan perlu membangun kerjasama dengan Prodi dan menampung usulan Prodi terkait program kerja tahunan yang mereka buat sehingga bisa menampung inspirasi Prodi. Mereka merasa keberadaan Prodi tidak bisa dipisahkan dari organisasi mahasiswa, Prodi adalah orang tua mereka dikampus, sehingga apapun harus sepengetahuan Prodi mereka. Pada saat yang sama ada sebagian mahasiswa pengurus organisasi yang berpendapat tidak perlu melibatkan program studi dalam membuat program kerja organisasi, atas dasar pertimbangan bahwa organisasi mahasiswa adalah dari mahasiswa punya mahasiswa dan untuk mahasiswa, maka perlu diberikan kebebasan kepada mahasiswa untuk membuat dan mengambil keputusan dalam mengelola organisasi mereka. Dua acara pandang yang berbeda ini merupakan sebuah kewajaran yang terjadi dalam pengelolaan organisasi kemahasiswaan, tidak hanya di FS UAI begitujuga dengan organisasi sejenis di Fakultas lain bahkan universitas lain. Perbedaan cara pandang ini, setidaknya dipengaruhi oleh dua hal:

1. Cara mahasiswa dalam menterjemahkan Keputusan Menteri Pendidikan dan Kebudayaan Republik Indonesia NOMOR 155 /U/1998. Dimana dalam keputusan menteri ini dikatakan bahwa organisasi mahasiswa dikelola dari dan untuk mahasiswa, seakan-akan mengambarkan bahwa mahasiswa harus diberi kebebasan penuh dalam membuat, dan menjalankan organisasi mereka. Padahal, dalam konteks pendidikan yang baik, kita diharuskan untuk memberikan kepercayaan kepada mahasiswa dalam berorganisasi, dan diberikan kebebasan, akan tetapi pada saat yang sama pendidik juga harus memberikan masukan dan mengingatkan batasan-batasan yang tidak boleh dilanggar dalam berorganisasi.

2. Tingkat penguasaan keilmuan mahasiswa dalam berorganisasi yang masih beragam, keterbatasan pengalaman dan umur mereka dalam mengelola organisasi menyebabkan 
mereka berbeda dalam melihat satu masalah, sebagian mahasiswa lebih cendrung untuk melihat masalah secara singkat tampa melihat secara utuh, bahwa keberadaan organisasi intra kampus adalah satu kesatuan yang tidak bisa dipisahkan dengan universitas tempat organsiasi itu berada, apalagi organisasi berbasis ilmu pengetahuan.

\section{Pandangan Mahasiswa Sebagai Pengurus dalam membuat Program Kerja Sebagai Alat untuk Meningkatan Kemahiran Berbahasa}

Dalam mendapatkan data melihat cara pandang mahasiswa terkait tema ini, peneliti menuangkannya dalam empat pernyataan sebagai berikut:

a) Program kerja organisasi mahasiswa yang dibuat, harus menampung seluruh potensi yang ada dari seluruh anggota

b) Program kerja organisasi mahasiswa harus menunjang proses belajar mengajar yang diajarkan di Program Studi yang ada di FS

c) Program kerja organisasi mahasiswa harus mendukung mahasiswa untuk bisa menggunakan kemahiran berbahasa dengn baik

d) Program kerja organisasi kemahawiswaan harus sejalan dengan arah pengajaran yang dikembangkan oleh Program Studi

Kuliah dan Organisasi adalah dua kegiatan yang tidak terpisahkan dari diri seorang mahasiswa. Masing-masing mahasiswa memiliki hak untuk aktif dalam suatu organisasi ataupun tidak. Kuliah tanpa organisasi bagai kerupuk yang jika dimakan hanya mendapat anginnya saja. Mahasiswa hanya belajar teori di dalam kelas tanpa mampu mengaplikasikannya di dalam kehidupan sehari-hari dmasyarakat. Begitu juga organisasi, terlalu mengutamakan organisasi hingga melalaikan kuliah bagai pohon yang tidak berdaun.

Terkait dengan analisa yang dilakukan di sub bab ini, didapati data bahwa pengurus organisasi mahasiswa yang ada di Fakultas Sastra yang tergabung dalam KMF dan KMPS, menyikapi empat pernyataan diatas, bahwa hampir seluruh pengurus menyatakan bahwa dalam membuat program kerja, merupakan sebuah keharusan bagi mereka mengkaji kekuatan-kekuatan apa saja yang dimiliki oleh para anggota sebelum program kerja ini dibuat. Mereka juga sangat setuju jika keberadaan program kerja yang dibuat oleh pengurus organisasi mahasiswa di FS harus menunjang proses belajar mengajar yang diajarkan di Program Studi yang ada di FS, harus sejalan dan saling mendukung. Mereka merasa program kerja yang dibuat harus menunjang dan mendukung mereka untuk mampu menguasai kemahiran berbahasa asing yang mereka pelajari di masing-masing program studi yang ada. Maka oleh sebab itu program kerja organisasi kemahawiswaan yang ada di FS harus sejalan dengan arah pengajaran yang dikembangkan oleh Program Studi, dengan tetap mengedepankan kebebasan berpendapat dan berkreasi mahasiswa. Mereka perlu dibina dan diarahkan, jangan sampai terlena dan salah menempatkan, kapan harus aktif berorganisasi dan kapan waktu untuk belajar.

\section{Program kerja organisasi mahasiswa yang mendukung pengajaran kemahiran berbahasa (mendengar, berbicara, membaca, menulis):}

Berikut, peneliti ingin mengelompokan program kerja yang dibuat oleh masing-masing organisasi mahasiswa tingkat Fakultas Sastra yang terdiri dari satu KMF dan empat KMPS, khususnya yang mendukung proses pembelajaran kemahiran berbahasa yang empat, mendengar, berbicara, membaca dan menulis.

Adapun dalam menuangkan masing-masing program kerja ini, penulis mengelompokannya bersasarkan organisasi yang ada, dari bidang/devisi yang ada di masing-masing organisasi mahasiswa yang ada di Fakultas Sastra. Hanya program kerja berbasis kemahiran berbahasa saja yang ditampilkan, sebagaimana berikut ini:

Tabel 1. Program Kerja Keluarga Mahasiswa Fakultas Sastra (KMFS) Berbasis Kemahiran Berbahasa

\begin{tabular}{ccl}
\hline No & Devisi & \multicolumn{1}{c}{ Program Kerja } \\
\hline & & $\begin{array}{l}1 . \quad \text { Membantu } \\
\text { menyusun proker } \\
\text { mengenai kemahiran } \\
\text { bahasa mahasiswa/i } \\
\text { dalam satu periode. }\end{array}$
\end{tabular}




\begin{tabular}{|c|c|c|}
\hline No & Devisi & Program Kerja \\
\hline & & $\begin{array}{l}\text { 2. Membantu dan } \\
\text { mengawasi jalannya } \\
\text { proker mengenai } \\
\text { kemahiran bahasa }\end{array}$ \\
\hline 2 & Humas & $\begin{array}{l}\text { Membuat majalah } \\
\text { dinding (Mading) } \\
\text { tingkat KMF, yang } \\
\text { diterbitkan sebulan } \\
\text { sekali, mahasiswa } \\
\text { diminta berkreasi } \\
\text { dalam bentuk tulisan } \\
\text { dan pengurus } \\
\text { memajangnya di } \\
\text { Mading yang } \\
\text { dimiliki. }\end{array}$ \\
\hline 3 & $\begin{array}{c}\text { Pengembangan } \\
\text { Mahasiswa }\end{array}$ & $\begin{array}{l}\text { Mengadakan acara } \\
\text { Diaspora Sastra, } \\
\text { yaitu acara tahunan } \\
\text { yang dibagi kedalam } \\
\text { bidang akademik, } \\
\text { olahraga dan seni. } \\
\text { Dalam bidang } \\
\text { akademik seperti } \\
\text { lomba pidato, debat, } \\
\text { baca berita, reporter } \\
\text { dll, dengan } \\
\text { menggunakan } \\
\text { Bahasa asing yang } \\
\text { dipelajari di FS UAI }\end{array}$ \\
\hline 4 & $\begin{array}{l}\text { Sosial dan } \\
\text { Agama }\end{array}$ & $\begin{array}{l}\text { Mengadakan acara } \\
\text { Baikti Sosial } \\
\text { (Baksos) Bahasa. } \\
\text { Dalam acara Baksos } \\
\text { ini, mahasiswa diajak } \\
\text { untuk mengajarkan } \\
\text { Bahasa asing yang } \\
\text { mereka kuasai dalam } \\
\text { berbagai aktifitas, } \\
\text { seperi mengajar } \\
\text { berbicara, menulis, } \\
\text { menulis dan lain-lain } \\
\text { setiap tahunnya }\end{array}$ \\
\hline
\end{tabular}

Tabel 2. Program Kerja Keluarga Mahasiswa Program Studi Sastra Arab (KMPSA) Berbasis Kemahiran Berbahasa

\begin{tabular}{|c|c|c|}
\hline No & Bidang/Devisi & Program Kerja \\
\hline \multirow[t]{2}{*}{1} & \multirow[t]{2}{*}{$\begin{array}{l}\text { Ketua dan } \\
\text { Wakil }\end{array}$} & $\begin{array}{l}\quad \text { 1. Mengkondisikan } \\
\text { bagi seluruh bidang } \\
\text { yanga ada agar membuat } \\
\text { program kerja, } \\
\text { disamping keahlian lain, } \\
\text { juga harus membuat } \\
\text { program yang } \\
\text { berhubungan dengan } \\
\text { kemahiran bahasa }\end{array}$ \\
\hline & & $\begin{array}{l}\text { 2. Memantau dan } \\
\text { mengawal jalannya } \\
\text { program kerja yang } \\
\text { berhubungan dengan } \\
\text { kemahiran bahasa } \\
\text { 1. Membuat contoh } \\
\text { surat menggunakan } \\
\text { bahasa Arab }\end{array}$ \\
\hline 2 & $\begin{array}{c}\text { Sekretaris dan } \\
\text { Bendahara }\end{array}$ & $\begin{array}{l}\text { 2. Mengajarkan } \\
\text { anggota pengurus dan } \\
\text { non pengurus dalam } \\
\text { surat menyurat dalam } \\
\text { bahasa Arab }\end{array}$ \\
\hline \multirow[b]{2}{*}{3} & \multirow[b]{2}{*}{ Humas } & $\begin{array}{l}\quad 1 . \quad \text { Membuat } \\
\text { mading sebagai alat } \\
\text { kreasi menulis } \\
\text { mahasiswa } \\
\text { menggunakan bahasa } \\
\text { Arab }\end{array}$ \\
\hline & & $\begin{array}{l}\quad \text { 2. Menyediakan } \\
\text { wadah untuk pengurus } \\
\text { dan non pengurus } \\
\text { (anggota) untuk menulis } \\
\text { dengan menggunakan } \\
\text { bahasa Arab di mading } \\
\text { yang telah disediakan }\end{array}$ \\
\hline \multirow[b]{2}{*}{4} & \multirow{2}{*}{$\begin{array}{c}\text { PENSI } \\
\text { (Pendidikan } \\
\text { dan } \\
\text { Kontribusi) }\end{array}$} & $\begin{array}{l}\text { 1. Mengadakan } \\
\text { Yaumul Arobi atau hari } \\
\text { bahasa Arab setiap hari } \\
\text { rabu sore untuk melatih } \\
\text { kemahiran berbahasa } \\
\text { mahasiswa sastra Arab }\end{array}$ \\
\hline & & $\begin{array}{l}\quad 2 . \quad \text { Mengadakan } \\
\text { kursus dan lomba } \\
\text { mengetik bahasa Arab } \\
\text { yang diperuntukan bagi } \\
\text { seluruh pengurus dan } \\
\text { anggota KMPS Arab } \\
\text { UAI. }\end{array}$ \\
\hline
\end{tabular}




\begin{tabular}{|c|c|c|}
\hline No & Bidang/Devisi & Program Kerja \\
\hline & & $\begin{array}{l}\quad \text { 3. Melatih dan } \\
\text { memperlancar serta } \\
\text { membantu mahasiswa } \\
\text { dalam materi } \\
\text { percakapan bahasa Arab } \\
\text { ketika dilaksanakan } \\
\text { acara Yaumul Arobi atau } \\
\text { hari bahasa Arab }\end{array}$ \\
\hline & & $\begin{array}{l}\quad 4 . \quad \text { Melaksanakan } \\
\text { acara seminar tentang } \\
\text { kebahasaan bagi } \\
\text { mahasiswa, tingkat } \\
\text { nasional mengenai } \\
\text { bahasa Arab dan hal-hal } \\
\text { terkait dengan belajar } \\
\text { kemahiran berbahasa }\end{array}$ \\
\hline \multirow{3}{*}{5} & \multirow{3}{*}{$\begin{array}{l}\text { MIKAT } \\
\text { (Minat dan } \\
\text { Bakat) }\end{array}$} & \begin{tabular}{l}
\multicolumn{1}{c}{ 1. Membuat } \\
kelompok/komunitas, \\
dari berbagai bidang \\
keahlian, seperti \\
Jurnalisme, Kaligrafi, \\
debat, puisi, menyanyi \\
dalam bahasa Arab bagi \\
pengurus dan non \\
pengurus KMPS Arab.
\end{tabular} \\
\hline & & $\begin{array}{l}\quad \text { 2. Mengikuti } \\
\text { perlombaan dan } \\
\text { pertandingan baik loka, } \\
\text { nasional dan } \\
\text { internasional yang } \\
\text { berhubungan dengan } \\
\text { kemahiran berbahasa } \\
\text { Arab }\end{array}$ \\
\hline & & $\begin{array}{l}\quad \text { 3. Mengadakan } \\
\text { acara Festival @ Arabia, } \\
\text { yaitu perlombaan } \\
\text { nasional mengenai } \\
\text { bahasa Arab tingkat } \\
\text { SMA dan Perguruan } \\
\text { Tinggi satu kali dalam } \\
\text { satu tahun }\end{array}$ \\
\hline 6 & $\begin{array}{c}\text { SAGA (Sosial } \\
\text { dan Agama) }\end{array}$ & $\begin{array}{l}\quad 1 . \text { Mengadakan } \\
\text { acara Himpunan } \\
\text { Mahasiswa Sastra Arab } \\
\text { (HIMASA) mengajar, } \\
\text { yaitu kegiatan mengajar } \\
\text { bahasa Arab kepada } \\
\text { anak-anak TPA dan anak } \\
\text { yang mebutuhkan }\end{array}$ \\
\hline
\end{tabular}

Tabel 3. Program Kerja Keluarga Mahasiswa Program Studi Sastra China (KMPSC) Berbasis Kemahiran Berbahasa

\begin{tabular}{|c|c|c|}
\hline No & Devisi & Program Kerja \\
\hline \multirow[t]{2}{*}{1} & \multirow{2}{*}{$\begin{array}{c}\text { Ketua dan } \\
\text { Wakil }\end{array}$} & $\begin{array}{l}\text { 1. Mengadakan Kursus } \\
\text { Xuexibu, dengan tujuan } \\
\text { membantu mahasiswa } \\
\text { yang mengalami kesulitan } \\
\text { dalam belajar kemahiran } \\
\text { berbahasa China. } \\
\text { Dilakukan perkelompok } \\
\text { dan dibimbing dosen dari } \\
\text { Pusat Bahasa Mandarin } \\
\text { (PBM) }\end{array}$ \\
\hline & & $\begin{array}{l}\text { 2. Mengadakan Kursus } \\
\text { Shufa dengan tujuan } \\
\text { mengajarkan kaligrafi } \\
\text { dulu maupun sekarang } \\
\text { kepada mereka yang } \\
\text { tertarik dengan keindahan } \\
\text { tulisan China, } \\
\text { memperkuat kemahiran } \\
\text { menulis mahasiswa }\end{array}$ \\
\hline 2 & Sekretaris & $\begin{array}{l}\text { Mengadakan kursus } \\
\text { paduan suara dalam } \\
\text { bentuk, membantu } \\
\text { mahasiswa/i dalam } \\
\text { mengartikan lagu China } \\
\text { dan pelafalan yang benar, } \\
\text { melatih kemahiran } \\
\text { membaca dan berbicara } \\
\text { dalam bentuk pelafalan }\end{array}$ \\
\hline 3 & $\begin{array}{l}\text { Humas } \\
\text { KMPS }\end{array}$ & $\begin{array}{l}\text { Mengadakan kursus } \\
\text { Wushu, kegiatan ini } \\
\text { mengajarkan budaya } \\
\text { turun-menurun Chinayang } \\
\text { dikenal banyak orang, } \\
\text { kegiatan ini lebih bersifat } \\
\text { olah raga, akan tetapi } \\
\text { pelatih menggunakan } \\
\text { Bahasa China dalam } \\
\text { pengantar hariannya } \\
\text { karena langsung diasuh } \\
\text { oleh dosen Pusat Bahasa } \\
\text { Mandarin UAI }\end{array}$ \\
\hline
\end{tabular}


Tabel 4. Program Kerja Keluarga Mahasiswa Program Studi Sastra Inggris (KMPSI) Berbasis Kemahiran Berbahasa

\begin{tabular}{|c|c|c|}
\hline No & Bidang/Devisi & Program Kerja \\
\hline \multirow[b]{2}{*}{1} & \multirow[b]{2}{*}{$\begin{array}{c}\text { Ketua dan } \\
\text { Wakil }\end{array}$} & $\begin{array}{l}\text { 1. Membuat dan } \\
\text { mengawasi program } \\
\text { kerja selama satu } \\
\text { tahun kepengurusan. }\end{array}$ \\
\hline & & $\begin{array}{l}\text { 2. Menambah } \\
\text { kegiatan } \\
\text { mahasiswa/i yang } \\
\text { dapat meningkatkan } \\
\text { kemampuan } \\
\text { berbahasa Inggris }\end{array}$ \\
\hline 2 & Humas & $\begin{array}{l}\text { Membuat Mading } \\
\text { Mingguan, untuk } \\
\text { menggali bakat dan } \\
\text { minat mahasiswa } \\
\text { dalam aspirasi karya } \\
\text { mahasiswa dan } \\
\text { memberinya } \\
\text { apresiasi yang } \\
\text { tinggi. }\end{array}$ \\
\hline 3 & $\begin{array}{l}\text { Pendidikan } \\
\text { dan Sosial }\end{array}$ & $\begin{array}{l}\text { Mengadakan Bakti } \\
\text { Sosial Sastra } \\
\text { Inggris, dalam } \\
\text { bentuk mengajarkan } \\
\text { bahasa Inggris } \\
\text { kepada anak-anak } \\
\text { dan remaja }\end{array}$ \\
\hline
\end{tabular}

Tabel 5. Program Kerja Keluarga Mahasiswa Program Studi Sastra Jepang (KMPSJ) Berbasis Kemahiran Berbahasa

\begin{tabular}{|c|c|c|}
\hline No & Bidang/Devisi & Program Kerja \\
\hline 1 & Ketua & $\begin{array}{l}\text { Pembuatan Short } \\
\text { Film/video. } \\
\text { Dalam kegiatan } \\
\text { ini anggota } \\
\text { diharapkan dapat } \\
\text { mengapresiasikan } \\
\text { diri, selain itu } \\
\text { dapat } \\
\text { memperlancar } \\
\text { pelafalan bahasa } \\
\text { Jepang, karena } \\
\text { teks yang } \\
\text { digunakan }\end{array}$ \\
\hline
\end{tabular}

\begin{tabular}{ccl}
\hline No & Bidang/Devisi & \multicolumn{1}{c}{ Program Kerja } \\
\hline & & berbasis Jepang \\
\hline & Membuat mading \\
& jurusan, yang \\
& tujuannya adalah \\
& membantu \\
& & mahasiswa/i \\
& & dalam menulis \\
& Sekretaris & dan membaca \\
& & bahasa Jepang \\
& & dengan baik dan \\
& & benar \\
\hline
\end{tabular}

Dari kelima organisasi kemahasiswaan yang ada di Fakultas Sastra UAI sebagaimana yang tergambar dari data diatas, didapati bahwa ada beberapa program kerja yang telah dibuat dan dilaksanakan oleh organisasi mahasiswa yang menunjang proses pembelajaran kemahiran berbahasa asing yang dilakukan di Fakultas Sastra UAI. Walupun masih beragam bentuk, jumlah dan program antara masing-masing organisasi mahasiswa yang ada. Ada yang menjadikan kemahiran sebagai subjek/fokus kegiatan, ada juga yang masih belum maksimal dalam mendesain program yang dilaksanakan. Pada saat yang sama ada bagian atau devisi yang seharusnya melaksananakan program yang menjadi tanggung jawabnya di organisasi , akan tetapi justru mereka melaksanakan program lain yang tidak ada korelasinya dengan jabatan yang diembannya dalam organisasi. Hal ini membuktikan masih perlunya pembekalan, pendampingan bagi mahasiswa Fakultas Sastra dalam mengelola organisasi, membuat program kerja, menjalankan program kerja yang sesuai dengan tupoksi mereka masing-masing.

\section{Saran pengurus organisasi mahasiswa dalam meningkatkan kemampuan kemahiran berbahasa asing melalui Organisasi Mahasiswa Fakultas Sastra:}

Pada bagian akhir dari analisa penelitian ini, peneliti ingin mengetahui usulan dan masukan dari pengurus organisasi kemahasiswaan yang ada di Fakultas Sastra terkait dengan peran yang seharusnya dilakukan oleh organisasi kemahsiswaan Fakultas Sastra kedepan, khususnya dalam konteks peningkatan kemampuan mahasiswa dalam kemahiran berbahasa asing, sebagaimana berikut ini:

1. Sudah seharusnya organisasi mahasiswa berjalan seiringan dengan apa yang 
menjadi tanggung jawab program studi dalam mengajar mahasiswa kemahiran berbahasa, sehingga bisa menjadi penyeimbang dan mendukung pembelajaran yang dilaksanakan di dalam kelas

2. Organisasi mahasiswa di Fakultas Sastra harus mampu merangkum kekuatan mahasiswa dan menjadi wadah pengembangan bakat dan minat mahasiswa FS

3. Pengurus organisasi kemahasiswaan di Fakultas Sastra harus membuat program kerja dengan memperbanyak kegiatan dalam menumbuhkan dan mengembangkan potensi mahasiswa yang ada di Fakultas Sastra

4. Organisasi mahasiswa di Fakultas Sastra harus terus bersinergi dengan dosen dan Program Studi dalam membuat dan melaksanakan program kerja yang telah dicanangkan.

5. Program yang dibuat oleh organisasi mahasiswa di Fakultas Sastra UAI, diharapkan mampu mengeksplor kemampuan bahasa asing mahasiswa/i dengan metode-metode yang menarik dan menyenangkan, seperti dengan games permainan, lomba, pameran dan lain-lain.

6. Program kerja organisasi kemahaiswaan yang dibuat harus selaras dengan visi dan misi program studi dalam mengajarkan Bahasa dan budaya. Kegiatan yang dilakukan diluar kelas diharapakan bisa membantu mahasiswa menguasi keilmuan yang dipelajari didalam kelas.

7. Disamping untuk mendukung proses pembelajaran, organisasi mahasiswa juga dijadikan sebagai ladang untuk melatih diri dalam keahlian lain yang tidak dipelajari didalam kelas, yang dapat melahirkan kompetensi lain yang dibutuhkan mahasiswa setelah mereka menamatkan kuliah dan bekerja dibidangnya masing-masing/kompetensi pendukung di dunia kerja.

8. Problem utama yang dihadapi oleh organisasi mahasiswa Fakultas Sastra saat ini adalah rasa memiliki anggota kepada organisasi yang masih sangat kurang, maka kedepannya perlu ada upaya bersama untuk menjadikan organisasi mahasiswa di FS menjadi organisasi kemahasiswaan yang ideal, yang mampu mengikis habis sikap apatis para anggota.

\section{KESIMPULAN}

Dari hasil analisa penelitian yang telah dilakukan, dapat ditarik kesimpulan sebagi berikut:

1. Pola pembinaan organisasi kemahasiswaan di Fakultas Sastra, Universitas Al Azhar Indonesia, berbeda dengan yang diterapkan di Fakultas lain di UAI. Konsep kekeluargaan menjadi dasar pngelolaan organisasi, bahkan sampai berpengaruh kepada penamaan yang dipilih untuk seluruh organisasi yang ada: Keluarga Mahasiswa Universitas (KMU) untuk organisasi mahasiswa tingkat universitas, Keluarga Mahasiswa Fakultas (KMF), untuk organisasi mahasiswa tingkat fakultas, Keluarga Mahasiswa Program Studi (KMPS) untuk organisasi mahasiswa tingkta program studi, dan Unit Keluarga Kegiatan Mahasiswa (UKKM) untuk minat dan bakat. Dengan penanggung jawab: Rektor/Wakil Rektor bidang kemahasiswaan bertanggung jawab membina KMU, Dekan Fakultas bertanggung jawab membina KMF, dan Ketua Program Studi bertanggung jawab membina KMPS, sementara untuk UKKM disyaratkan harus dibina oleh salah seorang dosen atau staf yang memilik hobi yang sama dengan UKKM yang mereka bina.

2. Program kerja yang dibuat dan dilaksakan oleh organisasi kemahasiswaan yang ada di FS UAI yang sudah menunjang proses pembelajaran kemahiran berbahasa yang empat (mendengar, berbicara, membaca dan menulis) yang dilakukan, dari sebagian bidang/devisi yang ada, akan tetapi belum begitu maksimal dalam melaksanakankan dan mengelolanya.

3. Partisipakasi keaktifan dan keikutsertaan ang mahasiswa Fakultas Sastra yang tergabung dalam organisasi KMFS dan KMPS (Arab, China, Inggris, Jepang), masih perlu untuk ditingkatkan lagi. Di beberapa organisasi tingkat partisipasi mahasiswa sangat kecil, diantara penyebab masih kurangnya rasa memilki dan keaktifan mahasiswa ini dipengaruhi oleh kesadaran mereka akan pentingnya organisasi dan kekurang mampuan mereka terkait pentingnya aktif seorang mahasiswa dalam satu organisasi. 


\section{SARAN}

Ada beberapa saran untuk pengelolaan dan pengembangan organisasi mahasiswa di Fakultas Sastra, Universitas Al Azhar Indonesia.

1. Perlu pendampingan dan pembinaan yang kongkrit dalam pengelolaan organisasi yang ada oleh pejabat dimana organisasi kemahasiswaan itu berada, baik ditingkat universitas, fakultas, program studi dan minat bakat, agar keberadaan organisasi tepat sasaran.

2. Perlu dilakukan pelatihan secara terprogram yang diperuntukan bagi mahasiswa yang menjadi pengurus dan calon pengurus. Pelatihan ini dilaksanakan atas kerjasama fakultas, program studi dengan organisasi kemahasiswaan yang ada, agar proses kaderisasi mahasiswa dalam berorganisasi bisa berjalan secara kontiniu dan berkesinambungan.

3. Perlu dilakukan upaya bersama mengingatkan dan memberikan penyadaran kepada mahasiswa peran penting untuk aktif berorganisasi. Organisasi diperuntukan tidak saja untuk melatih soft skill dan membina kerjasama dan net working, akan tetapi organisasi bisa dijadikan alat membantu proses pembelajaran kemahiran berbahasa asing di Fakultas Sastra dan Program Studi yang ada di UAI.

\section{DAFTAR PUSTAKA}

[1] Kreshna W. Bondan, Cara Cerdas Pilih Jurusan, Demi Profesi Impian. 2010, Yokyakarta, Jokya Great

[2] Hutapea Parulian, Nurliana Thoha, Kompetensi Plus, Teori, Desain, Kasus, dan Penerapan untuk HR dan Organisasi yang Dinamis, 2008, Jakarta. Gramedia Pustaka Utama.

[3] Mochammad Ainin. Metodelogi Penelitian Bahasa Arab, 2007, Hilal, Bandung

[4] Subiyakto, Sri Utari dan Nababan. Metodologi Pengajaran Bahasa. Jakarta : P.T Gramedia Pustaka Utama, 1993. Fahmi, Ismail The Indonesian Digital Library Network.

[5] Makmun Abin Syamsududin, Psikologi Pendidikan, Bandung, Remaja Rosdakarya, 1990

[6] Buku Pedoman Akademik Universitas Al Azhar Indonesia, Cetakan tahun 2015.

[7] Peraturan Universitas Al Azhar Indonesia No. 001 tahun 2013, tentang Tata Kelola Organisasi Mahasiswa di UAI.

[8] http://srisukopujilestari.blogspot.co.id/201 1/07/pengalaman-pembelajaran.html

[9] https://nanangfuad.files.wordpress.com

[10] http://www.berkuliah.com/2014/10/tipsmembagi-waktu-kuliah-dan.html

[11] http://galaksiilmu89.blogspot.co.id/2012/0 6/teori-pemerolehan-bahasa.html 